\title{
RESPONS PERTUMBUHAN DAN EKSPRESI GEN UDANG VANAME, Litopenaeus vannamei SETELAH DIRENDAM DALAM LARUTAN HORMON PERTUMBUHAN REKOMBINAN IKAN KERAPU KERTANG
}

\author{
Siti Subaidah",*), Odang Carman ${ }^{* * *}$, Komar Sumantadinata***), \\ Sukenda ${ }^{* * *}$, dan Alimuddin ${ }^{* * *}$ \\ ") Mahasiswa Pascasarjana Ilmu Akuakultur, Departemen Budidaya Perairan \\ Fakultas Perikanan dan IImu Kelautan (FPIK), Institut Pertanian Bogor, Bogor 16680 \\ E-mail: ibeth_bambang@yahoo.com \\ *) Balai Budidaya Air Payau Situbondo, Direktorat Jenderal Perikanan Budidaya, KKP RI \\ Jl. Raya Pecaron, PO Box 5 Panarukan, Situbondo \\ $\left.{ }^{* * *}\right)$ Departemen Budidaya Perairan, FPIK, Institut Pertanian Bogor \\ Jl. Lingkar Akademik, Kampus IPB Darmaga, Bogor 16680
}

(Naskah diterima: 29 Agustus 2012; Disetujui publikasi: 30 Oktober 2012)

\begin{abstract}
ABSTRAK
Pertumbuhan ikan dapat ditingkatkan menggunakan hormon pertumbuhan rekombinan. Penelitian ini bertujuan mengkaji respons pertumbuhan dan ekspresi gen udang vaname, Litopenaeus vannamei setelah direndam dengan hormon pertumbuhan rekombinan ikan kerapu kertang, Epinephelus lanceolatus ( $\mathrm{rE} / \mathrm{GH})$. Pada percobaan pertama, post larva stadia 2 (PL-2) sebanyak 1.500 ekor direndam selama 1 jam dalam 1 liter air laut yang mengandung rE/GH lima dosis berbeda, yaitu 150; 15; 1,5; 0,15; dan $0,015 \mathrm{mg} / \mathrm{L}$ dan bovine serum albumin $0,01 \%$. Setiap perlakuan diulang $3 \mathrm{kali}$. Perendaman dilakukan dalam kantong plastik ditambah oksigen (volume air: oksigen = 1:5). Udang dipelihara dalam akuarium volume 60 liter dengan kepadatan 25 ekor/liter sampai PL-14. Hasil penelitian menunjukkan bahwa dosis $15 \mathrm{mg} / \mathrm{L}$ memberikan peningkatan bobot badan, panjang badan, dan sintasan tertinggi $(P<0,05)$ masingmasing sebesar 37,77\%; 12,75\%; dan 9,45\% dibandingkan dengan kontrol. Ekspresi mRNA single insulin binding domain (SIBD) pada PL-14 yang dianalisis dengan realtime PCR menunjukkan kenaikan sebesar 3,3 kali pada udang yang direndam $\mathrm{rEIGH}$ dibandingkan dengan kontrol, dan dapat dinyatakan bahwa SIBD berperan penting dalam induksi pertumbuhan. Tingkat ekspresi moult inhibiting hormone meningkat sekitar 13\%, sedangkan ekspresi cyclopilin A pada udang yang direndam rEIGH sama dengan kontrol. Pada percobaan kedua, perendaman PL-2 dalam larutan $\mathrm{rEIGH}$ dosis $15 \mathrm{mg} / \mathrm{L}$ dengan lama waktu 3 jam meningkatkan bobot badan sebesar 62,18\% lebih tinggi daripada perendaman 1 jam. Dengan demikian, perendaman udang dalam larutan rEIGH meningkatkan pertumbuhan dan ekspresi gen SIBD, dan metode ini dapat berguna dalam peningkatan produksi budidaya.
\end{abstract}

KATA KUNCI: udang vaname, hormon pertumbuhan rekombinan, perendaman, pertumbuhan, ekspresi gen

ABSTRACT: Growth response and genes expression of white shrimp Litopenaeus vannamei immersed in recombinant giant grouper growth hormone solution. By: Siti Subaidah, Odang Carman, Komar Sumantadinata, Sukenda, and Alimuddin 
Fish growth can be improved by using recombinant growth hormone. This research was aimed to examine the growth response and genes expression of white shrimp, Litopenaeus vannamei after immersed by different doses of recombinant giant grouper, Epinephelus lanceolatus growth hormone (rEIGH). At the first experiment, a total of 1,500 post larvae at stadia $2(P L-2)$ was bath immersed for one hour in $1 \mathrm{~L}$ sea water containing five different doses of $\mathrm{rEIGH}$, namely $150,15,1.5,0.15$, and $0.015 \mathrm{mg} / \mathrm{L}$, and $0.01 \%$ bovine serum albumin. Each treatment was triplicates. Immersion was performed in a plastic bags supplied by oxygen (water volume : oxygen $=1: 5$ ). Shrimp was then reared until reach PL-14 stage in $60 \mathrm{~L}$ aquarium at density of 25 shrimp per liter. The results showed that the dosage of $\mathrm{rEIGH} 15 \mathrm{mg} / \mathrm{L}$ revealed highest increment in body weight, body length and survival by $37.77 \%, 12.75 \%$, and 9.45\% compared to control $(P<0.05)$, respectively. Expression level of single insulin binding domain (SIBD) MRNA analyzed by quantitative real-time PCR analysis in rElGH-immersed PL-14 was about 3.3-fold higher than the control, and this suggested that SIBD plays important role in growth induction. Expression level of moult inhibiting hormone increased about 13\%, while expression of cyclopilin A in rEIGH treated shrimp was similar to that of control. At the second experiment, immersion of PL-2 in 15 $\mathrm{mg} / \mathrm{L} \mathrm{rEIGH}$ solution for 3 hours increased body weight of $62.18 \%$ higher compared to 1 hour immersion treatment. Thus, immersion of shrimp in rEIGH solution could increase growth and SIBD gene expression, and this technique can be useful to increase aquaculture production.

KEYWORDS: white shrimp, recombinant growth hormone, immersion, growth, gene expression

\section{PENDAHULUAN}

Hormon pertumbuhan rekombinan $(\mathrm{rGH})$ merupakan protein yang diproduksi oleh bioreaktor seperti bakteri Escherichia coli yang membawa vektor ekspresi gen hormon pertumbuhan. Produksi rGH menggunakan bioreaktor dilakukan setelah diketahui bahwa pemberian hormon pertumbuhan alami dapat memacu pertumbuhan, dan gen penyandinya berhasil diisolasi. Berbagai rGH ikan telah berhasil diproduksi seperti rGH ikan salmon (Sekine et al., 1985), rGH ikan flounder (Jeh et al., 1998), rGH orange-spotted grouper ( $\mathrm{Li}$ et al., 2003); rGH ikan patin siam (Poen, 2009), $\mathrm{rGH}$ ikan mas "rCcGH", rGH ikan gurame "rOgCH" dan rGH ikan kerapu kertang "rE/GH" (Alimuddin et al., 2010).

Penelitian aplikasi rGH untuk meningkatkan pertumbuhan umumnya dilakukan pada ikan, di antaranya pada ikan black seabream (Spondyliosoma cantharus) (Tsai et al., 1997), ikan nila (Oreochromis niloticus) (Li et al., 2003; Acosta et al., 2007; Alimuddin et al., 2010; Hardiantho et al., 2012), ikan giant catfish (Pangasianodon gigas) (Promdonkoy et al., 2004), ikan beronang (Siganus guttatus) (Funkenstein et al., 2005), ikan mas (Cyprinus carpio) (Utomo, 2010), ikan gurame (Osphronemus gouramy) (Irmawati et al., 2012; Syazili, 2012) dan ikan sidat (Alimuddin et al.,
2012). Aplikasi rGH pada udang, khususnya udang vaname masih sangat terbatas. Selain itu, "hormon pertumbuhan" udang belum diketahui dan tentu rekombinannya juga belum ada. Dari referensi yang dapat diakses, dua kelompok peneliti telah melakukan riset penggunaan $\mathrm{rGH}$ pada udang. Sonnenschein (2001) melakukan perendaman yuwana udang (bobot badan awal $90 \mathrm{mg}$ ) dengan bovine somatotropin (bST) dosis $300 \mathrm{mg} / \mathrm{L}$ selama 1 jam. Perendaman dilakukan satu kali, kemudian udang dipelihara sampai 2 bulan, terbukti menunjukkan peningkatan bobot badan sebesar $38 \%$ dan panjang badan sebesar $11 \%$ dibandingkan dengan kontrol. Selanjutnya, Santiesteban et al. (2010) merendam post larva udang vaname dengan rGH ikan nila (rtiGH) dosis $100 \mu \mathrm{g} / \mathrm{L}$ dengan frekuensi 7 kali, dan hasilnya pertumbuhan udang meningkat sekitar $42,4 \%$ dibandingkan dengan kontrol.

Hasil penelitian Santiesteban et al. (2010) menunjukkan bahwa rGH ikan dapat menginduksi pertumbuhan udang, sementara Sonnenschein (2001) memperlihatkan bahwa perendaman satu kali dapat menginduksi pertumbuhan udang secara signifikan. Selanjutnya, dosis yang digunakan oleh Santiesteban et al. (2010) yakni $100 \mu \mathrm{g} / \mathrm{L}$, lebih rendah daripada yang digunakan oleh Sonnenschein (2001) yakni 300 mg/L. Namun 
demikian, Sonnenschein (2001) melakukan perendaman satu kali dengan menggunakan bST, sedangkan Santiesteban et al. (2010) merendam 7 kali menggunakan rtiGH. Secara teknis, perendaman satu kali lebih praktis. Selain itu, penggunaan rGH dan kemurnian berbeda sangat berpeluang memberikan peningkatan pertumbuhan yang berbeda. Perendaman udang vaname satu kali dengan dosis rGH ikan lain diduga akan memberikan hasil yang sama atau bahkan lebih tinggi daripada capaian Santiesteban et al. (2010). Dari hasil penelitian Irmawati et al. (2012) diketahui bahwa tingkat produksi rE/GH lebih tinggi daripada $\mathrm{rCcGH}$ dan $\mathrm{rOgGH}$. Dosis $\mathrm{rElGH}$ untuk menghasilkan peningkatan pertumbuhan yang sama pada ikan gurame juga lebih rendah daripada $\mathrm{rCcGH}$ (Irmawati et al., 2012), sehingga penggunaan rE/GH lebih efisien daripada $\mathrm{rCc} \mathrm{CH}$. Oleh karena itu, pada penelitian ini digunakan rE/GH. Perendaman glass eel ikan sidat dalam larutan $\mathrm{rElGH}$ dosis $12 \mathrm{mg} / \mathrm{L}$ meningkatkan bobot badan sebesar $37,4 \%$ dibandingkan dengan kontrol (Handoyo, 2012). Dosis perendaman pada udang vaname menggunakan rE/GH diduga akan lebih tinggi daripada yang digunakan pada ikan sidat, karena kulit luar (eksoskeleton) udang keras.

Pada vertebrata, insulin dan insulin-like growth factor-I (IGF-I) merupakan pemain kunci dalam regulasi proses anabolik dalam metabolisme. Pada krustase fungsi peptida mirip insulin ini belum jelas, tetapi dalam penelitian Gutie' rrez et al. (2007) menunjukkan adanya insulin in vivo, sedangkan Castellanos et al. (2008) menunjukkan adanya protein single insulin binding domain (SIBD) dari L. vannamei yang mempunyai similaritas tinggi dengan IGF binding protein ditemukan pada hemosit. Pada penelitian ini ekspresi gen SIBD dianalisis untuk mengevaluasi keterkaitan perubahan laju pertumbuhan udang vaname akibat perlakuan $\mathrm{rEIGH}$.

Pertumbuhan krustase berhubungan dengan penggantian kulit (moulting) (Keller, 1992). Moulting dikontrol oleh hormon ecdysteroid dari Y-organ dalam cepalotorak dan dihambat oleh hormon penghambat (molt inhibiting hormone/MIH) dari kelenjar Xorgan (Baldaia et al., 1984; Tangprasittipap et al., 2010). Selanjutnya Tangprasittipap et al. (2010) menemukan lima kandidat yang menyerupai gen pertumbuhan (homologi tinggi), yaitu cyclophilin, cyclophilin $A$, fibrillarin, SPARC, dan PC2. Cyclophilin A (CypA) mempunyai korelasi yang tinggi terhadap bobot badan udang windu, Penaeus monodon. Oleh karena itu, pada penelitian ini juga dilakukan analisis ekspresi gen CypA dan $\mathrm{MIH}$ untuk mengevaluasi keterkaitan perubahan laju pertumbuhan udang vaname akibat perlakuan $\mathrm{rE} / \mathrm{GH}$.

\section{BAHAN DAN METODE}

\section{Produksi rEIGH}

Vektor ekspresi pCold/rE/GH dan metode yang digunakan untuk memproduksi $r E / G H$ mengacu pada Alimuddin et al. (2010). Bakteri Escherichia coli hasil kultur diendapkan menggunakan sentrifugasi, dan diresuspensi dengan phosphate buffer saline (PBS) yang mengandung $0,1 \%(\mathrm{w} / \mathrm{v})$ Triton X-100, kemudian dilakukan sonikasi ( 1 menit hidup dan 1 menit mati) sebanyak 6 siklus dengan amplitudo $14 \%$. Suspensi yang terbentuk kemudian disentrifugasi, dan supernatan dibuang. Pelet dibilas sebanyak 2 kali dengan $1 \mathrm{M} \mathrm{NaCl}$ yang mengandung $1 \%(\mathrm{w} / \mathrm{v})$ Triton $\mathrm{X}$ 100 , dan terakhir dibilas dengan PBS. Sonikasi berfungsi melisis sel-sel dinding bakteri, oleh sebab itu, untuk mendapatkan rEIGH yang lebih bersih diuji dengan 12 siklus sonikasi, dan juga penggantian sonikasi dengan lysozim, untuk kemudian bioaktivitas protein dianalisis.

Badan inklusi (protein total) yang mengandung rEIGH dianalisis menggunakan metode sodium dodecyl sulfate-polyacrylamide gel electrophoresis (SDS-PAGE) untuk verifikasi keberadaan dan konsistensi produksi rEIGH. Prosedur pengerjaan SDS-PAGE dilakukan berdasarkan metode Walker et al. (2002) menggunakan gel akrilamid 15\%. Marker ukuran protein yang digunakan adalah prestained protein marker (Promega). Ukuran protein rEIGH berdasarkan prediksi yakni sekitar 22 $\mathrm{kDa}$, terdeteksi pada sampel dengan sonikasi 12 siklus (Gambar 1, lajur 1.1), sampel dengan sonikasi 6 siklus (Gambar 1, lajur 1.2), dan sampel dengan lysozim (Gambar 1, lajur 2.1). Bobot protein rElGH yang terkandung dalam badan inklusi diukur menggunakan nanodrop spektrofotometer. Selanjutnya protein $\mathrm{rEIGH}$ disimpan di lemari pendingin $-80^{\circ} \mathrm{C}$ sebelum digunakan untuk perlakuan. Selain itu, dalam penelitian ini dilakukan juga penyimpanan $\mathrm{rEIGH}$ di lemari pendingin $-20^{\circ} \mathrm{C}$ selama 1 bulan, dan seperti ditunjukkan pada Gambar 1 lajur 3.1 bahwa secara visual tidak ada perubahan komposisi dan konsentrasi setiap protein. 


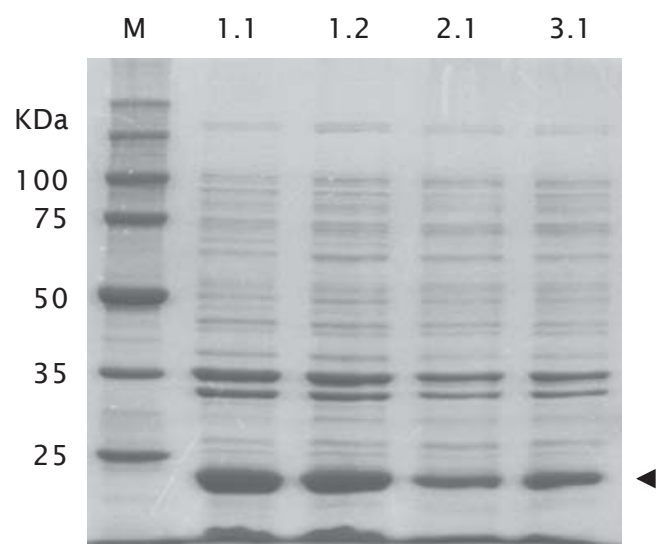

Gambar 1. Hasil analisis SDS-PAGE terhadap badan inklusi Escherichia coliyang mengandung rE/GH (ditunjukkan dengan tanda kepala panah). $\mathrm{M}=$ marker protein prestained protein marker (Promega). Lajur 1.1 = sampel produksi rEIGH dengan sonikasi 12 siklus; Lajur 1.2 = sampel produksi rElGH dengan sonikasi 6 siklus; Lajur 2.1 = sampel produksi $r E / G H$ dengan lysozim ; Lajur 3.1 = sampel rElGH disimpan di $-20^{\circ} \mathrm{C}$ selama 1 bulan

Figure 1. The results of SDS-PACE analysis of inclusion bodies Escherichia coli containing rElGH (indicated by arrow head). $M=$ marker proteins prestained protein marker (Promega). Row 1.1 = sample of $r$ ElGH production with 12 cycles sonication; Row 1.2 = sample of $\mathrm{rEIGH}$ production with 6 cycles sonication; Row $2.1=$ sample of $r E I G H$ production with lysozim; Row 3.1 = sample of $\mathrm{rEIGH}$ was stored for 1 month in $-20^{\circ} \mathrm{C}$

Dengan demikian penyimpanan di lemari pendingin $-20^{\circ} \mathrm{C}$ sekitar 1 bulan dapat dilakukan bila tidak memiliki lemari pendingin $-80^{\circ} \mathrm{C}$.

\section{Penentuan Dosis Perendaman}

Protein $\mathrm{rEIGH}$ yang digunakan adalah produksi $\mathrm{rEIGH}$ dengan sonikasi 6 siklus. Penentuan dosis rEIGH berdasarkan hasil penelitian Handoyo (2012) yakni pemberian rEIGH pada glass eel ikan sidat secara imersi dan diperoleh dosis terbaik $12 \mathrm{mg} / \mathrm{L}$ dengan sekali perendaman. Dengan asumsi udang membutuhkan dosis yang lebih tinggi karena udang memiliki eksoskeleton yang keras, maka dosis tertinggi dibuat menjadi $150 \mathrm{mg} / \mathrm{L}(\mathrm{Pl})$ dan dilakukan penurunan dosis menjadi 15 (P2); 1,5 (P3); 0, 15 (P4); dan 0,015 mg/L (P5). Sebagai kontrol adalah perendaman $15 \mathrm{mg} \mathrm{L}^{-1}$ badan inklusi pCold tanpa sisipan $\mathrm{GH}\left(\mathrm{K}^{+}\right)$; dan tanpa perendaman (K). Masing-masing perlakuan dilakukan ulangan 3 kali dengan desain rancangan acak lengkap.

Hewan uji adalah post larva udang vaname stadia dua (PL-2) yang diperoleh dari pembenihan udang di Situbondo. Penelitian dilakukan di Balai Budidaya Air Payau Situbondo, dengan menggunakan akuarium berukuran $(45 \mathrm{~cm} \times 45 \mathrm{~cm} \times 45 \mathrm{~cm})$ dengan volume air 60 liter dan kepadatan awal 25 ekor per liter. Udang vaname PL-2 sebanyak 1.500 ekor direndam selama 60 menit dengan air laut 1 liter yang mengandung larutan $\mathrm{rE} / \mathrm{GH}$ sesuai dosis masing-masing perlakuan ditambah bovine serum albumin (BSA) 0,01\%. Perendaman dilakukan dengan cara memasukkan PL-2 tersebut ke dalam plastik kemas volume 6 liter dan diberi oksigen dengan perbandingan volume air : oksigen adalah 1:5.

Parameter kualitas air dikontrol agar media selalu dalam kondisi layak. Pemeliharaan untuk semua perlakuan dihentikan setelah PL-14. Pakan yang diberikan adalah pakan buatan bentuk flake (serpihan) dengan kadar protein 48\%, dan nauplii Artemia. Jumlah pakan buatan untuk PL-2 - PL-1 4 adalah 2-4 mg/L per aplikasi yang diberikan 5 kali sehari, sedangkan nauplii Artemia sebanyak 10-20 nauplii per ekor post larva udang dan diberikan 2 kali sehari.

Untuk menentukan dosis perendaman rEIGH terbaik, dilakukan pengamatan pertumbuhan bobot dan panjang badan. Pengukuran bobot dan panjang dilakukan 6 hari sekali. Bobot diukur dengan mengambil 40 ekor post larva udang secara acak dari setiap akuarium, kemudian ditimbang secara total dengan timbangan analitik (ketelitian 0,001 mg) Pengukuran panjang total dilakukan terhadap 10 ekor udang dengan menggunakan mistar.

Jumlah udang yang hidup setiap akuarium di akhir penelitian dihitung untuk setiap akuarium, kemudian dibagi dengan jumlah penebaran awal, dikalikan $100 \%$ untuk menentukan sintasan. Selanjutnya pada akhir penelitian dilakukan penimbangan udang secara total untuk setiap akuarium untuk mendapatkan biomassa. 


\section{Penentuan Lama Waktu Perendaman}

Setelah diperoleh dosis terbaik, penelitian dilanjutkan untuk menentukan lama waktu perendaman yang memberikan pertumbuhan dan sintasan terbaik. Lama waktu perendaman yang diuji adalah 2 dan 3 jam. Lama waktu pengamatan adalah 18 hari seperti yang dilakukan oleh Laksana (komunikasi pribadi, 2012). Metode perendaman dan pemeliharaan udang dilakukan seperti dijelaskan sebelumnya. Parameter yang diukur adalah pertumbuhan bobot, panjang badan, dan sintasan, serta biomassa. Hasilnya dibandingkan dengan lama waktu perendaman 1 jam pada penelitian sebelumnya.

\section{Analisis Ekspresi Gen SIBD (IGF-like), MIH, dan CypA}

Ekspresi gen single insulin binding domain (SIBD), moult inhibiting hormone $(\mathrm{MIH})$, dan cyclophilin A (CypA) diukur pada awal dan akhir penelitian. Sampel awal adalah PL-2 sebelum dilakukan perendaman $\mathrm{rEIGH}$ sebanyak 50 ekor, dan sampel akhir adalah PL-14 dengan dosis perendaman terbaik sebanyak 9 ekor dari 3 ulangan yang diambil secara acak, dalam kondisi segar dilakukan ekstraksi RNA. RNA total diekstraksi dari sampel sekitar 10-25 mg menggunakan bahan isogen (TAKARA, Japan) dengan metode sesuai prosedur dalam manual. RNA total dilarutkan dengan DEPC sebanyak $50 \mu \mathrm{L}$.

Sintesis DNA komplementer (cDNA) dilakukan menggunakan kit Ready-To-Go YouPrime First Strand Beads (GE Healthcare, USA) dengan prosedur sesuai manual. Primer yang digunakan adalah oligo(dT3) (5'-gtaatacgaa taactatagggcacgcgtggtcgacggcccgggctggttttttttttttttt-'3) konsentrasi $1 \mu \mathrm{g} / 3 \mu \mathrm{L}$ sebanyak $3 \mu \mathrm{L}$ per sampel. Hasil sintesis diencerkan dengan menambahkan air steril SDW sebanyak $50 \mu \mathrm{L}$.

Tingkat ekspresi setiap gen tersebut dari masing-masing sampel dianalisis secara kuantitatif menggunakan real-time PCR (qPCR) dengan primer spesifik (Tabel 1). Primer didesain berdasarkan sekuen yang diakses pada GenBank, yaitu SIBD dengan nomor aksesi EU664996.1 (Castellanos et al., 2008), MIH dengan nomor aksesi DQ412566.1 (Chen et al., 2007), CypA dengan nomor aksesi EU164775.1 (Qiu et al., 2009), $\beta$ - aktin dengan nomor aksesi AF300705.2 (Sun et al., 2007).

Premik untuk setiap sampel running qPCR terdiri atas: $4 \mu \mathrm{L}$ Evagreen (Solis BioDyne) yang berisi bahan-bahan reaksi PCR dan fluorescent dye; $1 \mu \mathrm{L}$ primer specific forward; $1 \mu \mathrm{L}$ primer specific reverse; $12 \mu \mathrm{L} \mathrm{SDW}$; dan $2 \mu \mathrm{L}$ template cDNA. Analisis qPCR dilakukan dengan mesin Rotor Gene (Corbett research) dengan program: proses pre-denaturasi pada suhu $95^{\circ} \mathrm{C}$ selama 5 menit sebanyak 1 siklus; proses denaturasi pada suhu $95^{\circ} \mathrm{C}$ selama 30 detik sebanyak 40 siklus; proses annealing pada suhu $62,9^{\circ} \mathrm{C}$ selama 30 detik sebanyak 40 siklus; proses ekstensi pada suhu $72^{\circ} \mathrm{C}$ selama 30 detik sebanyak 40 siklus; dan proses melting pada suhu $62,9^{\circ} \mathrm{C}$ sampai $99^{\circ} \mathrm{C}$ dengan perpindahan suhu setelah 5 detik. Data-data amplifikasi yang terekam diolah dengan metode Livak \& Schmittgen (2011) untuk menghitung tingkat ekspresi gen, yang dinormalkan dengan $\beta$-aktin sebagai kontrol internal loading RNA dalam sintesis cDNA.

Tabel 1. Nama primer spesifik dan sekuen nukleotidanya

Table 1. Specific primer name and nucleotide sequence

\begin{tabular}{lc}
\hline $\begin{array}{c}\text { Nama primer } \\
\text { Primer name }\end{array}$ & \multicolumn{1}{c}{$\begin{array}{c}\text { Sekuen (urut an } \text { 5'-3') }^{\prime} \\
\text { Sequence (5'-3') }\end{array}$} \\
\hline $\begin{array}{l}\text { Forward SIBD (SIBD-F) } \\
\text { Reverse SIBD (SIBD-R) }\end{array}$ & AAATGGTACTGATTCCTGGGACAAG \\
Forward MIH (mih 1-F) & AGAATCATGAAACCTTGTCCCAGGA \\
Reverse MIH (mih-R) & ATTATACACTCATGTATCGGCTGGC \\
Forward CypA (CypA-F) & AGAGGCTTGTCCCAACAACTACAAT \\
Reverse CypA (CypA-R) & CTGTAAAGTTTCAGAACATTCCCCC \\
Forward $\beta$-aktin (Lvbac-F) & GAACACCTATCTTCTTTCACCACCT \\
Reverse $\beta$-aktin (Lvbac-R) & CCTCCACCATCAAGATCAAGATCAT \\
\hline
\end{tabular}




\section{Analisis Data}

Data pertumbuhan dan sintasan dianalisis dengan menggunakan analisis sidik ragam (Anova), dan jika terdapat pengaruh nyata dilanjutkan dengan uji Duncan. Ekspresi gen SIBD, CypA, dan MIH dianalisis secara deskriptif.

\section{HASIL DAN BAHASAN}

\section{Pertumbuhan Bobot dan Panjang Badan}

Pertumbuhan PL secara statistik berbeda nyata $(P<0,05)$ pada pengukuran hari ke-12 atau pada PL-14. Dari 5 dosis perlakuan perendaman, diperoleh hasil bahwa dosis $\mathrm{rE} / \mathrm{GH}$ $15 \mathrm{mg} / \mathrm{L}$ memberikan pertumbuhan bobot badan tertinggi dengan nilai $(17,199 \pm 2,378$ $\mathrm{mg})$ dan berbeda nyata $(P<0,05)$ dengan 4 perlakuan lainnya serta kontrol (perendaman pCold dan tanpa perendaman) (Tabel 2). Dosis rEIGH $15 \mathrm{mg} / \mathrm{L}$ memberikan peningkatan bobot badan sekitar $37,77 \%$ lebih tinggi daripada kontrol tanpa perendaman (K) dan 77,27\% lebih tinggi daripada kontrol perendaman pCold $(\mathrm{K}+)$.
Panjang post larva udang yang telah diberi perlakuan perendaman $\mathrm{rEIGH}$ dengan dosis 15 $\mathrm{mg} / \mathrm{Ljuga}$ memberikan pertumbuhan panjang badan tertinggi dengan nilai $(1,768 \pm 0,018 \mathrm{~cm})$ dan berbeda nyata $(P<0,05)$ dengan 4 perlakuan lainnya serta kontrol (perendaman dengan pCold dan tanpa perendaman) (Tabel 2). Dosis rE/GH $15 \mathrm{mg} \mathrm{L}^{-1}$ memberikan peningkatan panjang badan sebesar $12,75 \%$ lebih tinggi dibanding kontrol tanpa perendaman (K) dan 19,22\% lebih tinggi daripada kontrol dengan perendaman pCold $(\mathrm{K}+)$. Pertumbuhan bobot badan dan panjang badan post larva udang vaname pada kontrol tanpa perendaman (K) dan perendaman dengan pCold $(\mathrm{K}+)$ tidak berbeda nyata $(\mathrm{P}>0,05)$ (Tabel 2). Hal ini menunjukkan bahwa perlakuan pemberian protein E. coli tanpa $r E / G H$ tidak berdampak terhadap pertumbuhan.

Hormon pertumbuhan secara langsung menstimulasi pertumbuhan melalui mekanisme metabolisme protein, lemak, karbohidrat, dan secara tidak langsung menstimulasi pembentukan insulin growth factor (IGF-1) di hati (Moriyama \& Kawauchi, 2001). Selanjutnya IGF-1

Tabel 2. Bobot badan, panjang badan, sintasan, dan biomassa post larva udang vaname yang direndam dengan hormon pertumbuhan rekombinan ikan kerapu kertang ( $r E / G H)$ dibandingkan dengan kontrol

Table 2. Body weight, body length, survivals, and biomass of white shrimp post larvae immersed in recombinant giant grouper growth hormone (rEIGH) compared with controls

\begin{tabular}{ccccc}
\hline $\begin{array}{c}\text { Perlakuan } \\
\text { Treatment }\end{array}$ & $\begin{array}{c}\text { Bobot badan } \\
\text { Bodyweight }(\mathbf{m g})\end{array}$ & $\begin{array}{c}\text { Panjang badan } \\
\text { Bodylength }(\mathbf{c m})\end{array}$ & $\begin{array}{c}\text { Sintasan } \\
\text { Survival (\%) }\end{array}$ & $\begin{array}{c}\text { Biomassa } \\
\text { Biomass (g) }\end{array}$ \\
\hline P1 & $11.988 \pm 1.661^{\mathrm{a}}$ & $1.568 \pm 0.068^{\mathrm{a}}$ & $88.067 \pm 3.348^{\mathrm{b}}$ & $15.827 \pm 2.151^{\mathrm{a}}$ \\
P2 & $17.199 \pm 2.378^{\mathrm{b}}$ & $1.768 \pm 0.018^{\mathrm{b}}$ & $88.580 \pm 0.900^{\mathrm{b}}$ & $22.852 \pm 2.141^{\mathrm{b}}$ \\
P3 & $12.404 \pm 2.750^{\mathrm{a}}$ & $1.525 \pm 0.130^{\mathrm{a}}$ & $88.333 \pm 0.900^{\mathrm{b}}$ & $16.459 \pm 3.790^{\mathrm{a}}$ \\
P4 & $10.962 \pm 1.692^{\mathrm{a}}$ & $1.490 \pm 0.048^{\mathrm{a}}$ & $88.289 \pm 1.033^{\mathrm{b}}$ & $14.530 \pm 2.400^{\mathrm{a}}$ \\
P5 & $12.494 \pm 0.523^{\mathrm{a}}$ & $1.578 \pm 0.028^{\mathrm{a}}$ & $87.890 \pm 2.607^{\mathrm{b}}$ & $16.484 \pm 1.177^{\mathrm{a}}$ \\
K+ & $9.702 \pm 1.092^{\mathrm{a}}$ & $1.483 \pm 0.084^{\mathrm{a}}$ & $84.843 \pm 3.049^{\mathrm{b}}$ & $12.313 \pm 0.945^{\mathrm{a}}$ \\
K & $12.484 \pm 1.821^{\mathrm{a}}$ & $1.568 \pm 0.097^{\mathrm{a}}$ & $80.933 \pm 5.354^{\mathrm{a}}$ & $15.061 \pm 1.299^{\mathrm{a}}$ \\
\hline
\end{tabular}

Keterangan (Note):

Nilai ditampilkan dalam bentuk rerata dari 3 kali ulangan \pm SD. Huruf superscript yang berbeda pada kolom yang sama mengindikasikan perbedaan pengaruh perlakuan berdasarkan uji lanjut Duncan $(P<0,05)$. P1: $150 \mathrm{mg} \mathrm{L}^{-1} \mathrm{rEIGH}+$ 0,01\% BSA; P2: $15 \mathrm{mg} \mathrm{L}^{-1} \mathrm{rEIGH}+0,01 \% \mathrm{BSA} ; \mathrm{P3}: 1,5 \mathrm{mg} \mathrm{L}^{-1} \mathrm{rEIGH}+0,01 \% \mathrm{BSA} ; \mathrm{P} 4: 0,15$ $\mathrm{mg} \mathrm{L}^{-1} \mathrm{rEIGH}+0,01 \% \mathrm{BSA} ; \mathrm{P5}: 0,015 \mathrm{mg} \mathrm{L}^{-1} \mathrm{rEIGH}+0,01 \% \mathrm{BSA}$; $\mathrm{K}+$ : Perendaman badan inklusi pCold tanpa sisipan $\mathrm{GH}+0,01 \% \mathrm{BSA} ; \mathrm{K}$ : Tanpa perendaman $\mathrm{rGH}$ (Values are shown as the mean of 3 replicates \pm SD. Different superscript letters in the same column indicate differences in treatment effects by Duncan further test $(P<0.05)$. P1: $150 \mathrm{mg} \mathrm{L}^{-1} \mathrm{rEIGH}+0.01 \% \mathrm{BSA} ; \mathrm{P2}: 15 \mathrm{mg} \mathrm{L}^{-1} \mathrm{rEIGH}+0.01 \% \mathrm{BSA} ; \mathrm{P3}: 1.5 \mathrm{mg} \mathrm{L}^{-1}$ rEIGH + 0.01\% BSA; P4: $0.15 \mathrm{mg} \mathrm{L}^{-1} \mathrm{rEIGH}+0.01 \%$ BSA; P5: $0.015 \mathrm{mg} \mathrm{L}^{-1} \mathrm{rEIGH}+0.01 \%$ BSA; K+: Immersion $p$ Cold inclusion bodies without inserts $\mathrm{GH}+0.01 \% \mathrm{BSA}$; $\mathrm{K}$ : Without immersion of $r E I G H$ ) 
menstimulasi pembelahan mitosis kondrosit dan peleburan sulfat di dalam matriks tulang rawan sehingga terjadi pertumbuhan tulangtulang (Bolander, 2004). Hormon pertumbuhan rekombinan yang masuk ke tubuh udang mekanismenya belum diketahui secara pasti berperan secara langsung atau tidak langsung, tetapi secara pasti telah menunjukkan peningkatan pertumbuhan baik bobot maupun panjang badan post larva udang vaname.

Dosis pemberian $\mathrm{rGH}$ harus tepat, karena jika kandungan IGF-1 berlebih dapat memberikan umpan balik negatif pada kelenjar untuk tidak mensekresi GH (Moriyama \& Kawauchi, 2001), dan jika kekurangan, maka pertumbuhan relatif lambat. Fenomena ini terlihat pada perlakuan P1 (dosis $150 \mathrm{mg} \mathrm{L}^{-1}$ media) pertumbuhan lebih rendah daripada kontrol (K) walaupun tidak berbeda nyata $(P>0,05)$. Pada dosis yang lebih rendah ( $P 3: 1,5$ $\mathrm{mg} \mathrm{L}^{-1}$ media dan P5: 0,015 $\mathrm{mg} \mathrm{L}^{-1}$ media) pertumbuhan sama dengan kontrol (K) dan perlakuan P4 (dosis $0,15 \mathrm{mg} \mathrm{L}^{-1}$ media) pertumbuhan sama dengan kontrol $(\mathrm{K}+)$ atau lebih rendah dari kontrol (K).

Selanjutnya penelitian dikembangkan dengan lama waktu perendaman 2 dan 3 jam, serta waktu pengamatan sampai 18 hari. Hasil pengamatan dibandingkan dengan waktu perendaman 1 jam pada penelitian yang sama. Pada pengamatan hari ke-12 peningkatan bobot pada perendaman 2 jam dan 3 jam masih rendah, yaitu masing-masing 0,73\% dan 9,38\%; tetapi peningkatan panjang badan lebih besar, yakni $7,2 \%$ untuk perendaman 2 jam dan $16 \%$ untuk perendaman 3 jam (Tabel 3).

Peningkatan bobot badan udang perlakuan 3 jam $(62,21 \%)$ cukup tinggi setelah hari ke18 , sedangkan peningkatan panjang sebesar $12,29 \%$. Angka tersebut 2,3 kali lebih besar dibandingkan dengan perendaman 2 jam yang hanya meningkat $26,99 \%$ untuk bobot (Tabel 3). Lama perendaman $r E / G H$ sangat berpengaruh terhadap pertumbuhan khususnya bobot udang. Hasil pengamatan menunjukkan bahwa penyerapan $\mathrm{rGH}$ ke dalam tubuh udang membutuhkan waktu cukup lama ( 3 jam) untuk mendapatkan hasil yang optimal. Hal ini besar kemungkinan karena kondisi eksoskeleton yang keras pada udang, sehingga penyerapannya lambat. Perendaman 3 jam dengan dosis $15 \mathrm{mg} \mathrm{L}^{-1}$ ini hasilnya lebih tinggi daripada yang dilakukan oleh Sonnenchein (2001), yaitu dengan dosis $300 \mathrm{mg} \mathrm{L}^{-1}$ dan lama perendaman 1 jam terjadi peningkatan bobot badan $38 \%$ setelah pemeliharaan 2 bulan, tetapi lama pemeliharaan dan $\mathrm{rGH}$ yang digunakan tidak sama, demikian juga jumlah udang yang direndam, lingkungan, dan metode pemeliharaan adalah tidak sama.

Selain dosis dan lama pemberian $\mathrm{rGH}$, frekuensi perendaman rGH juga mempengaruhi peningkatan pertumbuhan pada udang. Frekuensi perendaman rGH 7 kali telah

Tabel 3. Peningkatan bobot dan panjang badan udang vaname setelah direndam dengan hormon pertumbuhan rekombinan ikan kerapu kertang $(r E / G H)$ selama 2 dan 3 jam dibandingkan dengan lama perendaman 1 jam

Table 3. Increment of body weight and length of white shrimp after immersed in recombinant giant grouper growth hormone ( $r E I G H)$ for 2 and 3 hours compared to 1 hour immersion

\begin{tabular}{lccc}
\hline & $\begin{array}{c}\text { Lama waktu } \\
\text { perendaman } \\
\text { Im mersion time }\end{array}$ & $\begin{array}{c}\text { Peningkatan bobot } \\
\text { Body weight } \\
\text { increment (\%) }\end{array}$ & $\begin{array}{c}\text { Peningkatan panjang } \\
\text { Body length } \\
\text { increment (\%) }\end{array}$ \\
\hline Pengamatan hari ke-12 & 2 jam (hour) & 0.73 & 7.20 \\
Observed at day 12 & 3 jam (hour) & 9.38 & 16.00 \\
\hline Pengamatan hari ke-18 & 2 jam (hour) & 26.99 & 10.05 \\
Observed at day 18 & 3 jam (hour) & 62.21 & 12.29 \\
\hline
\end{tabular}

Keterangan (Note):

Perendaman dilakukan selama 1, 2, dan 3 jam pada stadia PL-2. Nilai tersebut merupakan rataan dari 3 ulangan (Immersion was performed for 1, 2, and 3 hours at PL-2 stage. This value was an average of 3 replications) 
dilakukan oleh Santiesteban et al. (2010) pada post larva udang vaname dengan dosis 100 $\mu \mathrm{g} \mathrm{rtiGH}$ (kemurnian sekitar 95\%) per liter media perendaman setiap 3 hari sekali, dapat meningkatkan pertumbuhan bobot sebesar $42,4 \%$ pada pengamatan hari ke-24. Jika disetarakan dengan total protein badan inklusi yang mengandung $\mathrm{rGH}$, dosis rtiGH yang digunakan untuk perendaman adalah $7 \mathrm{mg}$ per liter media. Dengan dosis $\mathrm{rGH}$ lebih tinggi (15 $\mathrm{mg} \mathrm{L}^{-1}$ ) dan lama perendaman 3 jam, hasilnya lebih tinggi (terjadi peningkatan $62,21 \%$ dibanding $1 \mathrm{jam}$ ), sedangkan Santiesteban et al. (2010) dengan dosis $7 \mathrm{mg} \mathrm{L}^{-1}$ dan lama perendaman 1 jam, terjadi peningkatan $42,2 \%$ setelah 24 hari pemeliharaan.

\section{Sintasan dan Biomassa}

Dengan pemberian rE/GH yang dilakukan melalui perendaman terbukti efektif dapat meningkatkan ketahanan tubuh dalam menghadapi lingkungan pemeliharaan, sehingga udang yang bertahan hidup (survive) pada 5 perlakuan berbeda nyata $(P<0,05)$ dengan kontrol tanpa perendaman (K), sedangkan antara 5 perlakuan dan perendaman dengan pCold $(K+)$ tidak berbeda nyata $(P>0,05)$. Selanjutnya antara kontrol $\mathrm{K}$ dan $\mathrm{K}+$ tidak berbeda nyata $(P>0,05)$ (Tabel 2). Perlakuan P2 (dosis $15 \mathrm{mg} \mathrm{L}^{-1}$ media) memberikan peningkatan sintasan sebesar 9,45\% dibandingkan dengan kontrol K.

Dari hasil penelitian ternyata dengan pemberian rGH mampu meningkatkan imunitas, sehingga sintasan meningkat. Hal ini sesuai dengan pernyataan Castellanos et al. (2008) bahwa protein SIBD dari L. vannamei yang mempunyai kemiripan tinggi dengan IGFBP ditemukan pada hemosit, mengandung protein yang berkaitan dengan respons imun. Selanjutnya Sonnenschein (2001) menyatakan bahwa hormon pertumbuhan rekombinan sapi secara oral untuk yuwana udang pada budidaya mampu meningkatkan kekebalan udang dan juga meningkatkan pertumbuhan.

Sebagai tolok ukur produksi adalah biomassa. Perlakuan perendaman $15 \mathrm{mg} \mathrm{L}^{-1}$ media (P2) menunjukkan biomassa $(22,852 \mathrm{~g})$ tertinggi, sedangkan kontrol sebesar 15,061 g (Tabel 2). Biomassa udang yang diberi perlakuan perendaman $15 \mathrm{mg} \mathrm{L}^{-1}$ media mengalami peningkatan sebesar $51,730 \%$ dibandingkan dengan kontrol (K). Peningkatan biomassa pada perlakuan P2 lebih tinggi daripada peningkatan bobot, hal ini disebab- kan sintasan pada perlakuan P2 juga lebih tinggi dibandingkan dengan kontrol (K). Selanjutnya biomassa semua perlakuan pada akhir penelitian juga menunjukkan tren yang sama dengan pertumbuhan bobot dan panjang udang, karena sintasan pada semua perlakuan juga lebih tinggi dari kontrol (K).

\section{Ekspresi Gen SIBD, CypA, dan MIH}

Ekspresi gen SIBD pada udang yang telah diberi perlakuan $\mathrm{rEIGH}$ dengan dosis $15 \mathrm{mg}$ $\mathrm{L}^{-1}$ media (P2) meningkat sekitar $12,5 \mathrm{kali}$ dibandingkan sebelum perlakuan (level 0,498 ) (Gambar 2A), sedangkan ekspresi gen SIBD kontrol tanpa perendaman (K) pada akhir penelitian mengalami peningkatan sekitar 3,7 kali. Dengan demikian, perlakuan $\mathrm{rEIGH}$ menstimulir ekspresi gen SIBD sebesar 3,3 kali dibandingkan dengan kontrol. Peningkatan ekspresi gen SIBD sebesar 3,3 kali tersebut sejalan dengan peningkatan pertumbuhan bobot sebesar $37,77 \%$ dan peningkatan panjang badan sebesar 12,75\%. Dengan demikian SIBD berperan penting dalam induksi pertumbuhan pasca perlakuan $\mathrm{rEIGH}$, dan diduga melibatkan efek tidak langsung seperti halnya pada ikan (IGF-1). Hal ini sesuai dengan pernyataan Bolander (2004) bahwa pertumbuhan linier skeleton diperantarai oleh IGF-1, selanjutnya IGF-1 menstimulir pembelahan mitosis kondrosit dan peleburan sulfat di dalam matriks tulang rawan sehingga terjadi pertumbuhan tulang.

Tingkat ekspresi gen CypA pada perlakuan $15 \mathrm{mg} \mathrm{L}^{-1}$ media (P2) menunjukkan penurunan dari 1,038 menjadi 0,002 pada akhir penelitian (hari ke-12). Hal yang sama juga terjadi pada kontrol tanpa perendaman (K), terjadi penurunan tingkat ekspresi dari 1,038 menjadi 0,003 (Gambar 2B). Tangprasittipap et al. (2010) menemukan cyclophilin A (CypA) mempunyai korelasi yang tinggi terhadap bobot badan udang $P$. monodon. Untuk itu, dilakukan identifikasi dan pengukuran ekspresi gen CypA dan ternyata dengan penambahan $\mathrm{rEIGH}$ tidak menunjukkan adanya aktivitas CypA, bahkan ekspresi gen menurun dibandingkan pada awal sebelum perlakuan. Hasil identifikasi growth hormone $(\mathrm{GH})$ pada krustase belum jelas, tetapi beberapa penelitian pemberian $\mathrm{rGH}$ pada udang memberikan hasil nyata terhadap peningkatan pertumbuhan (Toullec et al., 1991; Sonnenschein, 2001; Santiesteban et al., 2010). 

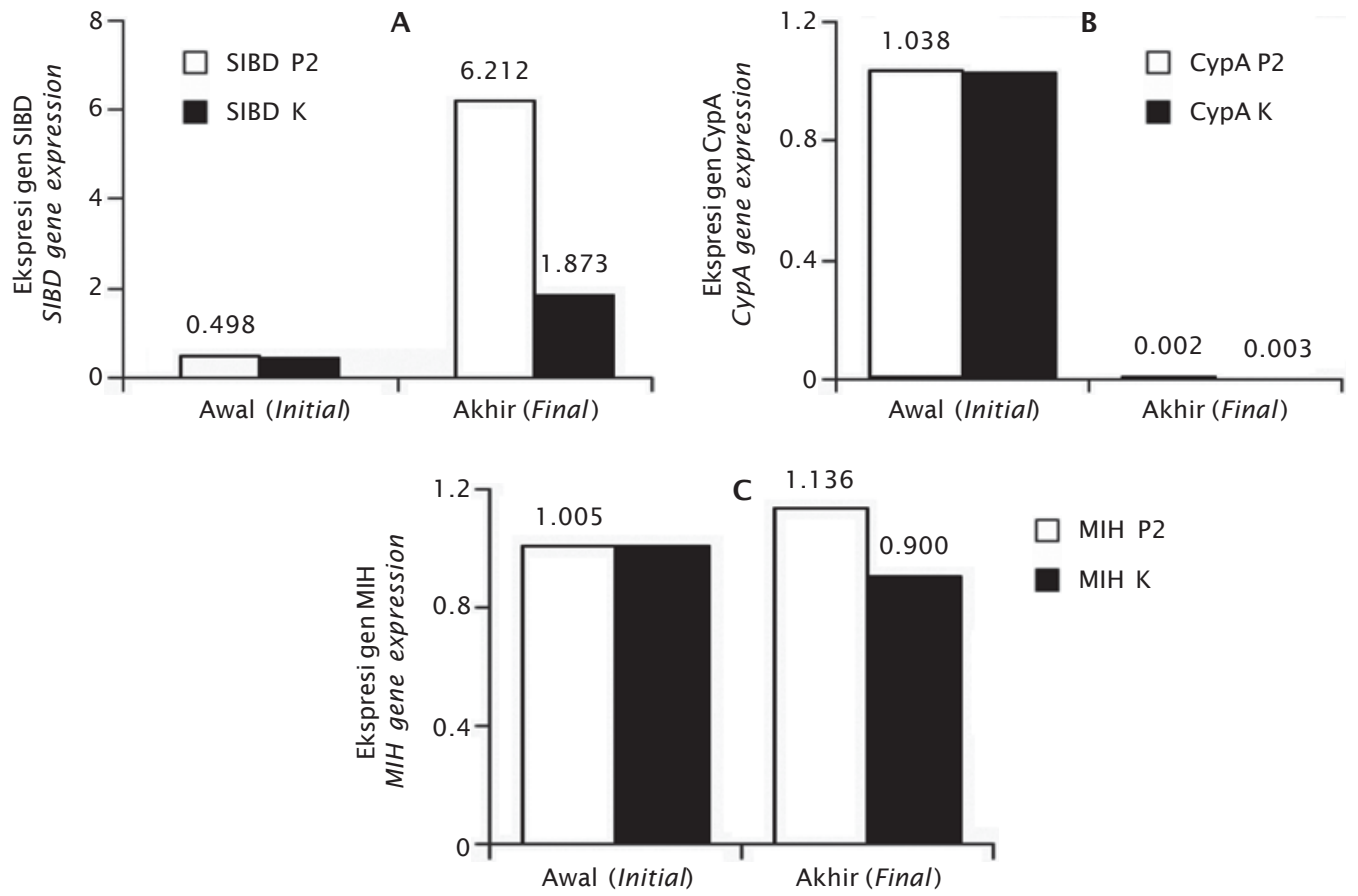

Gambar 2. Tingkat ekspresi gen SIBD (single insulin binding domain) (A), CypA (cyclophilin A) (B), dan $\mathrm{MIH}$ (moult inhibiting hormone) (C) pada awal (sebelum perendaman) dan 12 hari setelah perendaman hormon pertumbuhan rekombinan ikan kerapu kertang $(\mathrm{rEIGH})$ dosis $15 \mathrm{mg} \mathrm{L}^{-1}$ media (P2) dan tanpa perendaman (K). mRNA diekstraksi dari 50 ekor PL-2 (awal) dan 9 ekor PL-1 4 (akhir) dari populasi 3 ulangan. Tingkat ekspresi gen dianalisis menggunakan metode real-time PCR dan dinormalisasi dengan ekspresi gen $\beta$-aktin

Figure 2. Gene expression level of SIBD (single insulin binding domain) (A), CypA (cyclophilin A) $(B)$, and $\mathrm{MIH}$ (moult inhibiting hormone) (C) at early (before immersion) and 12 days after immersion in recombinant giant grouper growth hormone (rEIGH) at dose 15 $m g L^{-1}$ media $(P 2)$ and without immersion (K). The $m R N A$ was extracted from $50 \mathrm{PL}-2$ (early) and 9 PL-1 4 (end) of the population of 3 replications. Gene expression level was analyzed using real-time PCR and normalized to $\beta$-actin gene expression

Tingkat ekspresi gen MIH pada perlakuan perendaman $15 \mathrm{mg} \mathrm{L}^{-1}$ media (P2) terlihat ada kenaikan $13 \%$, sedangkan pada kontrol tanpa perendaman (K) terjadi penurunan dari 1,005 menjadi 0,900 (Gambar 2C). Hal ini menunjukkan bahwa perendaman rEIGH menginduksi ekspresi MIH. Moulting memiliki peran penting dalam pertumbuhan, ecdysteroid merupakan hormon yang bertanggung jawab dalam pertumbuhan, perkembangan dan reproduksi yang disintesis organ $\mathrm{X}$, sedangkan organ $\mathrm{Y}$ mensintesis MIH yang berperan menghambat sintesis ecdysteroid (Claerhout et al., 1996). Pengukuran sesaat pada MIH memang tidak dapat mencerminkan aktivitas pertumbuhan dalam jangka waktu tertentu, karena MIH ini meningkat pada saat akan terjadi moulting.
Dengan penggunaan $\mathrm{rEIGH}$ ini produksi budidaya diduga akan meningkat dan lebih efisien, karena dari penelitian ini setelah perendaman 12 hari dari PL-2 sudah dapat meningkatkan pertumbuhan bobot sebesar $37,77 \%$; panjang badan 12,75\%; sintasan 9,45\%; dan biomassa 50,73\%. Dengan kondisi tersebut stadia benih udang yang siap ditebar ke tambak dapat dipersingkat pada stadia sebelum PL-14 dengan sintasan yang lebih tinggi, sehingga produktivitas benih meningkat dan lebih efisien. Di samping itu, perlu kajian lebih lanjut pemeliharaan udang di tambak dengan atau tanpa pemberian $\mathrm{rGH}$, karena jika terjadi peningkatan biomassa di tambak akan sangat membantu petambak dalam meningkatkan produksinya. Pemberian 
rGH pada pembesaran udang telah dilakukan oleh Sonnenschein (2001) dan terbukti dapat meningkatkan bobot $38 \%$ dan panjang badan $11 \%$ setelah pemberian hormon pertumbuhan sapi (bST) sebanyak $300 \mathrm{mg} \mathrm{L}^{-1}$ media dalam sekali perendaman pada yuwana udang (bobot $90 \mathrm{mg}$ ) dan dipelihara sampai 2 bulan. Dari penelitian tersebut dapat dihitung efisiensi produksi minimal sebesar $38 \%$. Selain perendaman, metode pemberian $\mathrm{rGH}$ dapat dikombinasi dengan cara oral lewat pakan. Kombinasi ini sangat mungkin dilakukan pada udang, karena setelah post larva udang direndam rGH dapat dilanjutkan dengan pemberian lewat pakan pada periode pembesaran di tambak. Handoyo (2012) telah melakukan kombinasi metode perendaman dengan dosis

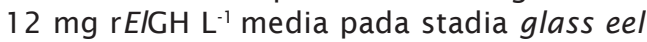
ikan sidat dan lewat pakan dengan dosis $30 \mathrm{mg} \mathrm{rE} / \mathrm{GH} \mathrm{kg}^{-1}$ pakan pada stadia elverikan sidat, memberikan peningkatan biomassa panen sebesar $102,9 \%$ dibandingkan dengan kontrol.

\section{KESIMPULAN}

Pemberian rElGH dengan metode perendaman berdampak pada pertumbuhan post larva udang vaname pada stadia PL-2-PL-14. Pertumbuhan terbaik diperoleh pada dosis $15 \mathrm{mg} \mathrm{L}^{-1}$ media. Peningkatan bobot, panjang badan, dan sintasan, serta biomassa pada perlakuan $15 \mathrm{mg} \mathrm{L}^{-1}$ media berturut-turut adalah sebesar $37,77 \%$; $12,75 \%$; 9,45\%; dan $50,73 \%$ dibandingkan dengan kontrol. Hasil pengukuran ekspresi gen SIBD (IGF-like) membuktikan bahwa pemberian $\mathrm{rEIGH}$ dengan dosis $15 \mathrm{mg} \mathrm{L}^{-1}$ media mampu menginduksi ekspresi SIBD sebesar 3,32 kali lebih besar dibandingkan dengan kontrol, dan menginduksi MIH sebesar 13\%, sedangkan ekspresi gen CypA tidak terinduksi.

\section{DAFTAR ACUAN}

Acosta, J., Morales, R., Morales, A., Alonso, M., \& Estrada, M.P. 2007. Pichia pastoris expressing recombinant tilapia growth hormone accelerates the growth of tilapia. Biotechnology Lett., 29: 1,671-1,676.

Alimuddin, Lesmana, I., Sudrajat, A.O., Carman, O., \& Faizal, I. 2010. Production and bioactivity potential of three recombinant growth hormones of farmed fish. Indonesian Aquaculture Journal, 5(1): 11-16.

Alimuddin, Handoyo, B., \& Utomo, N.B.P. 2012. 104 Inovasi Indonesia 2012. Institut Pertanian Bogor.
Bolander, F.F. 2004. Molecular Endocrinology, $3^{\text {rd }}$ ed. Elsevier Academic Press, London, $617 \mathrm{pp}$.

Baldaia, L., Porcheron, P., Coimbra, J., \& Cassier, P. 1984. Ecdysteroids in the shrimp Palaemon Serratus: relations with molt cycle. Gen. Comp. Endocrinol., 55: 437-443.

Castellanos, M, Jiménez-Vega, F., \& VargasAlbores, F. 2008. Single IB domain (SIBD) protein from Litopenaeus vannamei, a novel member for the IGFBP family. Comparative Biochemistry and Physiology, Part D, 3: 270-274.

Chen, H.Y., Watson, R.D., Chen, J.C., Liu, H.F., \& Lee, C.Y. 2007. Molecular characterization and gene expression pattern of two putative molt-inhibiting hormones from Litopenaeus vannamei. Gen. Comp. Endocrinol., 151:72-81.

Claerhout, T., Bendena, W., Tobe, S.S., \& Borst, D.W. 1996. Characterization of methyl transferase activity in the mandibular organ of the American lobster, Homarus americanus. Biol. Bull., 191: 304-304.

Funkenstein, B., Dyman, A., Lapidot, Z., de Jesus-Ayson, E.G., Gertler, A., \& Ayson, F.G. 2005. Expression and purification of a biologically active recombinant rabbitfish (Siganus guttatus) growth hormone. Aquaculture, 250: 504-515.

Gutie 'rrez, A., Nieto, J., Pozo, F., Stern, S., \& Schoofs, L. 2007. Effect of insulin/IGF-I like peptides on glucose metabolism in the white shrimp Penaeus vannamei. Gen. Comp. Endocrinol., 153: 170-175.

Handoyo, B. 2012. Respons benih ikan sidat terhadap hormon pertumbuhan rekombinan ikan kerapu kertang melalui perendaman dan oral. Tesis. Departemen Budidaya Perairan, Fakultas Perikanan dan IImu Kelautan, Institut Pertanian Bogor.

Hardiantho, D., Alimuddin, Prasetyo, A.E., Yanti, D.H., \& Sumantadinata, K. 2011 . Aplikasi Rekombinan Growth Hormon (rGH) Ikan Mas Pada Ikan Nila melalui Pakan Buatan. Makalah yang disampaikan dalam Pertemuan Broodstock Center Nila \& Temu Koordinasi Perekayasa Kementerian Kelautan dan Perikanan pada tanggal 15-17 November 2011.

Irmawati, Alimuddin, Zairin, M., Suprayudi, M.A., \& Wahyudi, A.T. 2012. Peningkatan laju pertumbuhan benih ikan gurame (Osphronemus gouramy Lac.) yang direndam dalam media yang mengandung 
hormon pertumbuhan ikan mas. Jurnal Iktiologi Indonesia (in press).

Jeh, H.S., Kim, C.H., Lee, H.K., \& Han, K. 1998. Recombinant flounder growth hormone from Escherichia coli: overexpression, efficient recovery, and growth-promoting effect on juvenile flounder by oral administration. Journal Biotechnology, 60: 183193.

Keller, R. 1992. Crustacean neuropeptides: structures, function and comparative aspects. Experientia, 48: 439-447.

Li, Y., Bai, J., Jian, Q., Ye, X., Lao, H., Li, X., Luo, J., \& Liang, X. 2003. Expression of common carp growth hormone in the yeast Pichia pastoris and growth stimulation of juvenile tilapia (Oreochromis niloticus). Aquaculture, 216: 329-341.

Livak, K.J. \& Schmittgen, T.D. 2001. Analysis of relative gene expression data using realtime quantitative PCR and the 2-ÄCT method. Methods, 25: 402-408.

Moriyama, S. \& Kawauchi, H. 2001. Growth Regulation by growth hormone and insulin-like growth factor-I in teleosts. Otsuchi Marine Science, 26: 23-27.

Poen, S. 2009. Cloning, over-expression and characterization of growth hormone from stripped catfish (Pangasianodon hypophthalmus). Tesis. Master of Science (Genetic Engineering) Graduate School, Kasetsart University.

Promdonkoy, B., Warit, S., \& Panyim, S. 2004. Production of a biologically active growth hormone from giant catfish (Pangasionodon gigas) in Escherichia coli. Biotechnol. Lett., 26: 649-653.

Qiu, L., Jiang, S., Huang, J., Wang, W., Zhu, C., \& $\mathrm{Su}, \mathrm{T}$. 2009. Molecular cloning and mRNA expression of cyclophilin A gene in black tiger shrimp (Penaeus monodon). Fish Shellfish Immunol., 26: 11 5-121.

Santiesteban, D., Martín, L., Arenal, A., Franco, R. \& Sotolongo, J. 2010. Tilapia growth hormone binds to a receptor in brush border membrane vesicles from the hepatopancreas of shrimp Litopenaeus vannamei. Aquaculture, 306: 338-342.
Syazili, A., Irmawati, Alimuddin, \& Sumantadinata, K. 2011 . Kinerja pertumbuhan dan kelangsungan hidup juvenil ikan gurame direndam hormon pertumbuhan rekombinan dengan frekuensi berbeda. Jurnal Akuakultur Indonesia, 10 (in press).

Sekine, S., Mizukami, T., Nishi, T., Kuwana, Y., Saito, A., Sato, M., Itoh, S., \& Kawauchi, H. 1985. Cloning and expression of cDNA for salmon growth hormone in Escherichia coli. Proc. Natl. Acad. Sci. USA, 82: 4,306-4,310.

Sonnenschein. 2001. Method of Enhancing Growth and Immunity of Shrimp Larvae Using Recombinant Bovine Growth Hormone. WIPO Patent Application WO/2005/ 115166.

Sun, P.S., Soderlund, M., Venzon, N.C.Jr, Ye, D., Lu, Y. 2007. Isolation and characterization of two actins of the pacific white shrimp, Litopenaeus vannamei. Mar. Biol., 151: 2,145-2,151.

Tangprasittipap, A., Tiensuwan, M., \& Withyachumnarnkul, B. 2010. Characterization of candidate genes involved in growth of black tiger shrimp Penaeus Monodon. Aquaculture, 307: 150-156.

Toullec, J.Y., Le Moullac GI, Gerad, C., Van Wormhoudt, A. 1991. Immunoreactive human growth hormone like peptides in tropical Penaeids and the effect of dietary hGH on Penaeus vannamei larval development. Aquat. Living Resour., 4: 125-132.

Tsai, H.J., Hsih, M.H., \& Kuo, J.C. 1997. Escherichia coli produced fish growth hormone as a feed additive to enhance the growth of juvenile black seabream (Acanthopagrus schlegeli). J. Appl. Ichthyol., 13: 78-82.

Utomo, D.S.C. 2010. Produksi dan Uji Bioaktivitas Protein Rekombinan Hormon Pertumbuhan Ikan Mas. Tesis. Departemen Budidaya Perairan, Fakultas Perikanan dan Ilmu Kelautan, Institut Pertanian Bogor.

Walker, J.M. 2002. The Protein Protocols Handbook. Second Edition. Human Press Inc., Totowa New Jersey. 